Volume 6 Issue 4, December 2019

Nationally Accredited Journal,

Decree No. B/4130/E5/E5.2.1/2019

\title{
Juridical Implementation of Distribution Assets for the Inheritance to Adopted by Islamic Law Compilation
}

\begin{abstract}
Noor Handayani ${ }^{1}$, Akhmad Khisni ${ }^{2}$ and Achmad Sulchan ${ }^{3}$
Abstract. The purpose of this study was to: 1) analyze the position adopted child's inheritance rights in Islamic Law Compilation (KHI). 2) to analyze the implementation of the division of property as inheritance to an adopted child Compilation of Islamic Law (KHI). 3) Analyze the legal consequences of the implementation of the division of property as inheritance to an adopted child Compilation of Islamic Law (KHI).

This study was prepared using the type of normative juridical research, the research focused on reviewing the application of the rules or norms of positive law. This study uses the approach of legislation (statute approach) And the approach of the case (case approach). The data collection was obtained by interview and literature. Analysis of data using qualitative descriptive.

The research results are: 1 ) Position Adopted in the Compilation of Islamic Law that adopted children may not be recognized to be the basis and cause of inherited, because the basic principle in Islamic inheritance law is their blood relations / nasab / descent. So as the solution according to Islamic law compilation is by jalam Award "was borrowed" on condition should not be more than 1/3 (one third). 2) The division of property as inheritance to an adopted child Compilation of Islamic Law (KHI) must meet two requirements that are required to accept the will not the beneficiary, the person who died both the grandfather and the grandmother has not provided to the child that must be made a will, the amount with other roads, such as grants for example, and if he has less than the sum was borrowed, then it should enhanced the will. 3) The role of the Notary in deed was borrowed for a foster child is doing what desired heir and explain all that heir to all the heirs, it is intended to provide clarity and legal certainty for all heirs of things execution of wills which heir to all his heirs.

Keywords: Inheritance, Adopted, Compilation of Islamic Law.
\end{abstract}

\section{Introduction}

Before the Islamic law of inheritance influenced by the social system espoused by the communities. Ignorant society with the pattern of the pattern tribal communities, have sedentary habits, belligerent and seize plunder. Most of them made their living trading. The trait seems to have become an established culture, or culture. Therefore the culture helped shape the values, the legal system and the prevailing social system. Physical strength and become a standard measure in the legal system legacy enactment. ${ }^{4}$

According jahiliyyah society, heirs who are entitled to the estate of a family who died were those men, stronger and defeat the enemy in every battle. Interest rate is preferred, because of the achievements and that the tribe's existence, the dignity of a person as a member of the tribe at stake. The consequence is that children of both men and women are not given the right to inherit the family legacy. Provisions of this kind have become a tradition and deeply rooted in society. In fact, as is well known,

\footnotetext{
${ }^{1}$ Student Master of Notary Program, Faculty of Law, Sultan Agung Islamic University Semarang, Email:norhandayani18@gmail.com

2 Lecturer of Faculty of Law, Sultan Agung Islamic University Semarang

${ }^{3}$ Lecurer of Faculty of Law, Sultan Agung Islamic University Semarang

${ }^{4}$ Akhmad Khisni, 2017, Hukum Waris Is/am, ed. Sixth, Semarang: Unissula Press, p. 21
} 
the phenomenon of live burials on girls, is a historical fact that can not be covered up. Practical women are treated very discriminative. They can not appreciate women, which later in the perspective of the Qur'an has the equal position with men. For them, women were not unlike like goods can be inherited and sold, can be possessed and transported. ${ }^{5}$

Solving the problems of marriage and inheritance Indonesian Muslim society adhering to the Islamic Law Compilation (KHI). The main source used in formulating $\mathrm{KHI}$ are texts of the Qur'an and As-Sunnah. The basic formulation or legal grounds contained in the Qur'an expressed with the formulation of a rational legal, practical and actual easily understood by the Muslim community in accordance with the spirit and the spirit of the teachings of Islam and pay attention as Asbabun Nuzul paragraph and as Asbabul Wurud of hadith. Thus, the general principles contained in the second source of Islamic law could be developed in accordance with the times and the circumstances of a place. ${ }^{6}$

In the development of Islamic legal thought, Islamic law can transformed into national law, the renewal of Islamic law must be carried out by way of developing the principles of Islamic law. Without the interaction between the principles of Islamic law with the development of society, the ideals wanted to embody Islamic law into national law can not be achieved. Legislation Islamic law is a manifestation of the most important Islamic modernism. With the integration of Islamic law with national law, then the problems of internal epistemology of Islamic law will be solved by itself. ${ }^{7}$

In inheritance law derived from the Qur'an, an adopted child can not inherit each other with their foster parents for not including class inherited causes, so that the adopted child is not the heir. There are only three things as the cause inherited, namely because of marriage, blood relationship and the freeing of a slave.

In the draft Civil Code as well as the rules of Islamic law which is commonly used to explain the inheritance, it is mentioned that the adopted child is not included in the list of one's heirs. According to Article 852 paragraph 1 of the Civil Code, the heir is:

Children or all their offspring, though born of others marriage once inherit from both parents, grandparents, or all of the family of flesh they are next in line straight up, with no distinction between male or female and no distinction based on first birth.

Meanwhile, based on Article 171 letter C Compilation of Islamic Law (KHI), heir described as people who at the time of death have blood ties or marriage relationship to the deceased, a Muslim and is not hindered by law to be an heir. The second article of the above, it is emphasized that the heirs are those who have blood relations / incest with heir. This is the legal basis which confirms that an adopted child can not be said to be the heir. Based on the above background, the authors take the title in the study "Implementation of the Judicial Review Division of Treasure Inheritance To Adopted Under Islamic Law Compilation".

This study tried to answer the question regarding the right position adopted children's inheritance in Islamic Law Compilation (KHI), the implementation of the division of property as inheritance to an adopted child Compilation of Islamic Law (KHI), and Role In Making Notary Deed was borrowed for Children Lift.

\section{Research methods}

\footnotetext{
${ }^{5}$ Rafiq Ahmad, 2002, Fiqh Mawaris, ed. Fourth, Jakarta: PT. Raja Grafindo Persada ,p. 8

${ }^{6}$ Mohammad Daud Ali, Principles of the Law of Inheritance in the Compilation of Islamic Law, in Pulpit Law No. 9 of IV 1993, p. 4

${ }^{7}$ Akhmad Khisni, 2015, Perkembangan Pemikiran Hukum Islam, The third Edition, Semarang:

Unissula Press, p.19
} 
Volume 6 Issue 4, December 2019

Nationally Accredited Journal,

Decree No. B/4130/E5/E5.2.1/2019

This study will be prepared using the type of normative juridical research, the research focused on reviewing the application of the rules or norms of positive law. ${ }^{8}$ Normative juridical, namely approach that uses the conception legis positivist, Methods of collecting legal material in this research is with interview and review of literature. Specifications of research used in the preparation of this thesis is a descriptive analytical research

\section{Results and Discussion}

\subsection{Position Adopted Inheritance Rights in Islamic Law Compilation (KHI)}

Adoption as has been stated by KHI (Compilation of Islamic Law) is treated as a child in terms of giving love living, education and services in all his needs are not treated as children "nasab" itself. Thus, in the view of Islamic law raised legal child is permissible or "may".

Adoption is prohibited under the provisions of Islamic law is like in the original sense, namely raised implicitly, in this case is to enter other people's children into their families that there is no linkage nasab to him as his own child, such as the right to receive an inheritance after his death and the prohibition of mating with her family. It is as Allah says in the Qur'an in Al Ahzab letter paragraphs 4 and 5, which reads:

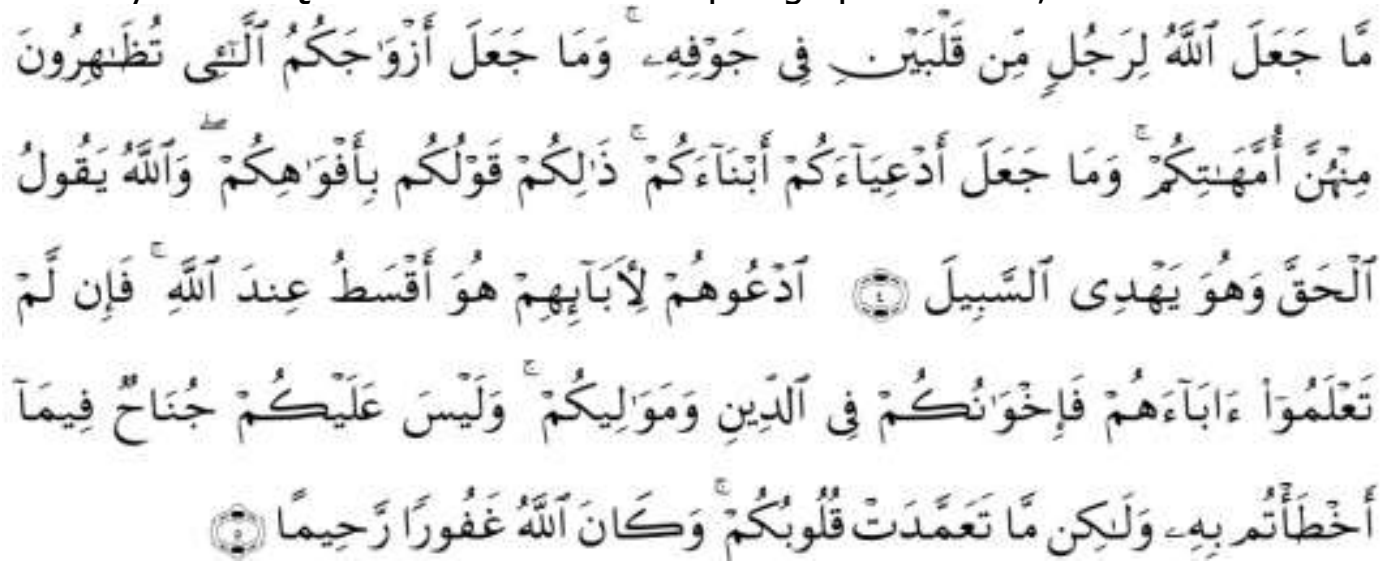

This means:

Allah has not made for a man two hearts in their sockets; has He made your wives whom you zhihar [1198] as a mother, has He made your adopted sons as your birth child (myself). Such a thing that are yours alone. and Allah is telling the truth and He shows the (right). Call them (the adopted sons) by (using) the name of their fathers; That is more equitable in the sight of God, and if you do not know their fathers, then (they call an as) your brothers in religion [1199]. and there is no sin for you in what you mistake him, but (which is sin) any willful heart. and Allah is Forgiving, Merciful.

Surah $A /-A h z a b$ are 4-5 in the outline can be formulated as follows:

- Foster child not own son;

- Call your adopted child by his father's name.

8 Johnny Ibrahim, 2006, Teori dan Metodologi Penelitian Hukum Normatif, Malang: Bayumedia Publishing, p. 295. 
From provisions of the above it is clear that what is prohibited is the adoption as biological children in all respects. It seems their crossover point Customary Law provisions in several regions in Indonesia, which eliminates or decide the position adopted child with his biological parents themselves. This is the principle of the adoption agency, because of the provisions that eliminate the rights of the biological father and to remodel the provisions regarding inheritance. Religion Islam encourages a Muslim to maintain other people's children who can not afford, the poor, displaced, and others. But is not allowed to disconnect and rights with his biological parents. Maintenance should be based solely on sponsorship, in accordance with the recommendation of God.

According to the formal Islamic law, adoption refers to KHI Article $171 \mathrm{~h}$ letter stated: "Adopted children are children in terms of maintenance for everyday life, educational expenses and so switching responsibility of the parents of origin to the adoptive parents under a court decision".

After the parents or the testator dies, the liability for the heir. Obligations of heirs under Article $175 \mathrm{KHI}$ are:

- Liabilities heir to heir is:

- Managing and finish until burial is complete

- Completing both debts in the form of medical treatment and care, including heir liabilities and receivables collection

- Completed testamentary heir

- Dividing the estate among the heirs are entitled to

- The responsibility of the heir to the heir to the debt or obligation is limited to the amount or value of legacy assets.

Adoption by KHI does not cause the breakup nasab or blood of a child with parents who gave birth to her. Islam explicitly gives the limits of the position adopted child in the family. It is certainly different from the position of adopted children in the Civil Code. In case of any inheritance, the adoptive parents may not inherit each with his adopted daughter, it is based that an inheritance based on the relationship nasab or legitimate offspring. Nonetheless, the right of adopted children remained a concern in Islam, where inheritance to an adopted child can do with was borrowed (Article 209 $\mathrm{KHI})$.

The position of adopted children by $\mathrm{KHI}$ is fixed as a legitimate child under a court decision not to sever ties with nasab or blood with his biological parents, because the principle of adoption by $\mathrm{KHI}$ is a manifestation of faith embodied in nurturing other people's children as a child in the form of care for children by maintaining all the needs and necessities of life. Was borrowed is that its implementation will not be affected or not depends on the will of those who died. This testament remain to be implemented, either spoken or desired or not by the person who died. So the implementation will not require proof that the will is spoken, written or desired, but the implementation is based on the legal grounds that justify that the stretcher will be implemented. ${ }^{9}$

In KHI, the provision was borrowed mentioned in Article 209 paragraph 1 and 2, which reads as follows:

- Treasure relics adopted children are divided by Articles 176 through 193 above, while against the adoptive parents who did not receive was borrowed by was borrowed as much $1 / 3$ of inheritance adopted.

\footnotetext{
${ }^{9}$ Suparno Usman, 2002, Fiqh Mawaris Hukum Kewarisan Islam, Jakarta: Style Media Pratama, p.16
} 
Volume 6 Issue 4, December 2019

Nationally Accredited Journal,

Decree No. B/4130/E5/E5.2.1/2019

- For adopted children who received the testament was given was borrowed, as much $1 / 3$ of the inheritance.

Regulations giving testament to the adopted child through was borrowed is actually considered to be new if it is linked with traditional fiqh, even legislation regarding inheritance prevailing in various the contemporary Islamic world. Qur'an explicitly reject the equation of the relationship because the adoption community that has grown in Arab Medina that time with the relationship because of consanguinity. ${ }^{10}$

\subsection{Implementation of the division of property as inheritance to an adopted child Compilation of Islamic Law (KHI)}

Under the provisions of Article 50 letter b of Law No. 3 of 2006, how settlement of property disputes referred to in paragraph (1) which is the subject of the law among people who are Muslims, the object of dispute is decided by the Religious Courts jointly referred to in Article 49. ${ }^{11}$ Its jurisdiction over the dispute heir stipulated in Article 49 letter b of Law No. 3 of 2006, which states that the court duty and authority to examine, decide and resolve cases at the first level among people who are Muslims in the field of inheritance.

There are two ways that can be taken by parents to provide foster fulfillment of child rights regarding inheritance. The way is by providing appropriate grants and KHI Civil Code or a will. Fulfillment of property rights foster child with foster parents in Islamic law does not actually need a will orally or in writing. When the adoptive parent dies, the adopted child shall be given was borrowed no bigger than $1 / 3$ treasures.

It is also described in the first paragraph of Article $209 \mathrm{KHI}$, which reads: "Against the foster child who did not accept the will, were given was borrowed as much as $1 / 3$ of the estate adoptive parents."

For the record, before the property is given to the adopted child, the rights of the legal heirs should be given first. KHI gave legal recognition to the existence of a foster child in the eyes of Islamic law while not leaving the main roots of the path that has been determined by God, namely the preservation of the sanctity of offspring ( hifdzu An-nas) which includes one of the five primary objectives of Islamic law, which nourishes the soul, intellect, lineage and property. Compilation of Islamic Law (KHI) provide a portion for adopted children in Islamic Inheritance Law that entered the ranks of those (heirs) who can or are entitled to a division of property inheritance adoptive parents, and vice versa, with the road construction through the modification of the path of Islamic Law was borrowed.

The implementation of the provision was borrowed must meet two (2) conditions namely: ${ }^{12}$

- Who shall receive a testament, not the heirs. If he is entitled to inheritance albeit slightly, it is not required to be made a will for him.

- People who died, both the grandfather and the grandmother has notthe child shall be made a will, the amount with other roads, such as grants for example. And if he has less than the sum was borrowed, the subject needs to be refined to the will.

\footnotetext{
${ }^{10}$ Ahmad Junaidi, 2011, Wasiat Wajibah : Pergumulan Hukum Adat dan Hukum Islam di Indonesia, First Edition, Jember: Pustaka Pelajar dan STAIN Jember Press, p. 91

${ }^{11}$ Mustafa, 2008, Pengangkatan Anak Kewenangan Pengadilan Agama, Jakarta: Sinar Grafika, p.134.

12 Tengku Muhammad, 2001, Fiqh Mawaris, Semarang: Pustaka Rizki Putra, p.8
} 
Basis can be used to make the rules on was borrowed against adopted children as provided for in Article $209 \mathrm{KHI}$ as part of fiqh is only through 'jtihad istishlah, 'urf, and istihsan method.

In civil law of Islam is only granted the pillars of the will, because if incorporated between consent and granted it farfetched, for how could the consent and granted implemented if the receiver will not be in place, for example in the state of the middle of the journey, or died suddenly. ${ }^{13}$ In Compilation of Islamic Law Article 194 states that a person can make one's requirements are:

- People who have lived at least 21 years, dietetic and without coercion can bequeath most of his property to another person or institution.

- property should be a right.

- The owner of the property as referred to in paragraph (1) of this article conducted after died.

Article 195 Compilation of Islamic law is the requirement to carry out the will, where a will:

- Probate is made orally in the presence of two witnesses, or written in presence of two witnesses in the presence of a notary.

- Probate is only allowed a maximum of one third (1/3) of the inheritance unless all heirs agree.

- Testament to the heirs is valid only when approved by all the heirs.

Article 196 as well as into the terms will reading "in a discrete both in writing and verbally stated firmly and clearly who or anyone or any agency designated to receive property". In theory, was borrowed defined as actions do ruler or judge as a state apparatus to force or compulsory decision will give the person who has died is given to certain people in certain circumstances. ${ }^{14}$

Application of the rules will set KHI done for two reasons, the first reason is to fill a legal vacuum. ${ }^{15}$ This argument is built on the basis that it was borrowed is a testament delivery system regulated by the state and has its legal basis in KHI, but at the same time KHI does not regulate in detail about was borrowed itself.

To overcome this, then the judge will rule in general use as the basis of the decision of granting was borrowed. The second reason related to the application of the rule of law is a will on was borrowed in order to create a sense of justice for the people. Provision was borrowed in particular the adopted child and the adoptive parents can realize justice, especially when there are emotional ties are very strong among adopted children with adoptive parents, so it would be very unfair if the foster child does not get the top of the estate owned by the parent adopted.

\subsection{Role In Making Notary Deed was borrowed for Children Lift}

The role of the notary is very important in helping to create certainty and legal protection for the community, because the notary as a public official authorized to make an authentic deed, as far as the manufacture of authentic deeds are not reserved for other public officials. Certainty and legal protection it looked through authentic deed he made as perfect evidence in court. Evidence is perfect for an

\footnotetext{
${ }^{13}$ Suhardi K. Lubis, 2008, Hukum Waris Islam, Jakarta: Sinar Grafika, p. 46

${ }^{14}$ Abdul Manan,1998, Beberapa Masalah Hukum Tentang Wasiat Dan Permasalahannya Dalam Konteks Kewenangan Peradilan Agama, (Mimbar Hukum Aktualisasi Hukum Islam Nomor 38 Tahun 1998, p. 23

${ }^{15}$ Nugraheni, Inspire, and Harahap, Settings and Implementation was borrowed, (Pulpit Law Volume 22, Number 2, June 2010), p. 316
} 
Volume 6 Issue 4, December 2019

Nationally Accredited Journal,

Decree No. B/4130/E5/E5.2.1/2019

authentic deed has three power outward evidence that the strength of evidence (uitwendige bewijsracht), the power of formal proof (formele bewijskracht) and the strength of evidence material (materiele bewijskracht). ${ }^{16}$

Given that the notary considered a respectable profession for a duty to serve the general public. Position respectable burdens and responsibilities for each notary to maintain the dignity and honor of the profession of notary. Dignity and honor of the profession notary office in performing their duties as public officials must be maintained, because it required the rules that regulate, restrict and serve as guidelines for the notary to hold office and behave.

Notary addition to being responsible in making the deed was borrowed also responsible for the implementation. In execution was borrowed this notary must carry out what is in the desired heir and explain all that heir to all the heirs, it is intended to provide clarity and legal certainty for all heirs of things execution testament heir to all heirs.

A notary deed at issue before the court in civil matters with a deed made by the notary, is more appropriate to bring a notary who made the deed as an expert witness. The presence of the notary who made the deed should be used as evidence in a case not as an ordinary witness but as an expert witness who will describe what the witness know according to witnesses expertise, relating to the issuance of a standard procedure notarial deed. ${ }^{17}$

\section{Closing}

\subsection{Conclusion}

Based on the description above, the conclusions of this research are:

- Position Adopted in the Compilation of Islamic Law that adopted children may not be recognized to be the basis and cause of inherited, because the basic principle in Islamic inheritance law is their blood relations / nasab / descent. In other words that the event of adoption under the laws of inheritance, no effect of law on the status of adopted children, if not the children themselves, can not inherit from those who have raised the child. So as the solution according to Islamic law compilation is by jalam Award "was borrowed" on condition should not be more than $1 / 3$ (one third).

- Implementation of the division of property as inheritance to an adopted child by Compilation of Islamic Law (KHI) must meet two (2) terms, namely:

- Who shall receive a testament, not the heirs. If he is entitled to inheritance albeit slightly, it is not required to be made a will for him.

- People who died, both the grandfather and the grandmother has not provided to the child that must be made a will, the amount with other roads, such as grants for example. And if he has less than the sum was borrowed, the subject needs to be enhanced the will.

- Notary Deed Role In Making Lift was borrowed for Children is responsible for making the deed was borrowed also responsible for the implementation. In execution was borrowed this notary must carry out what is in the desired heir and

\footnotetext{
${ }^{16}$ Ibid, p. 7

${ }^{17}$ Yuliana Pricilia Kambey, 2013, the role of the Notary in the Criminal Justice Process, Journal, Lex Et Societatis, Volume I Number 2, April-June, p. 30
} 
explain all that heir to all the heirs, it is intended to provide clarity and legal certainty for all heirs of things execution testament heir to all heirs.

\subsection{Suggestions}

- 1. It should be for people who will raise the child and give the child adopted Chinese-yam to find out more about information and related laws so as not to be used by parties who are not responsible.

- 2. Preferably notary in executing every deed was borrowed more concerned with the common interests of the interests of one party, so that the existence of each party are not left behind and get a position balanced, but if the was borrowed heirs agree to the excess part of the adopted child, the notary must noted, and if not approved by the heirs of the notary must account for his actions.

- 3. We recommend that in case the excess part of the adopted child, the judge lawsuits as late breakers should consider all aspects of the interests of the adopted child to the testator during his life, so that the rights of adopted children be protected.

\section{References}

[1] Abdul Manan,1998, Beberapa Masalah Hukum Tentang Wasiat Dan Permasalahannya Dalam Konteks Kewenangan Peradilan Agama, (Mimbar Hukum Aktualisasi Hukum Islam Nomor 38 Tahun 1998

[2] Rafiq Ahmad, 2002, Fiqh Mawaris, ed. Fourth, Jakarta: PT. Raja Grafindo Persada

[3] Ahmad Junaidi, 2011, Wasiat Wajibah : Pergumulan Hukum Adat dan Hukum Islam di Indonesia, First Edition, Jember: Pustaka Pelajar dan STAIN Jember Press

[4] Akhmad Khisni, 2015, Perkembangan Pemikiran Hukum Islam,cet. Third, Semarang: Unissula Press

[5] Akhmad Khisni, 2017, Hukum Waris Islam, ed. Sixth, Semarang: Unissula Press

[6] Johnny Ibrahim, 2006, Teori dan Metodologi Penelitian Hukum Normatif, Malang: Bayumedia Publishing.

[7] Mohammad Daud Ali, Asas-principle Inheritance Law in the Compilation of Islamic Law, Mimbar Hukum No. 9 Tahun IV 1993.

[8] Mustafa, 2008, Pengangkatan Anak Kewenangan Pengadilan Agama, Jakarta: Sinar Grafika

[9] Nugraheni, Inspire, and Harahap, Settings and Implementation was borrowed, Mimbar Hukum, Volume 22, Number 2, June 2010.

[10] Yuliana Pricilia Kambey, 2013,The role of the Notary in the Criminal Justice Process,Jurnal,Lex Et Societatis, Volume I Number 2.

[11] Suhardi K. Lubis, 2008, Hukum Waris Islam, Jakarta: Sinar Grafika

[12] Suparno Usman, 2002, Fiqh Mawaris Hukum Kewarisan Islam, Jakarta: Gaya Media Pratama

[13] Teungku Muhammad, 2001, Fiqh Mawaris, Semarang: Pustaka Rizki Putra 